\title{
THE POLITICAL ECONOMY OF AGRICULTURAL AND FOOD POLICIES
}

Johan Swinnen

Food and agriculture have been subject to heavy-handed government interventions throughout much of history and across the globe, both in developing and developed countries. ${ }^{1}$ Political considerations are crucial to understand these policies since almost all agricultural and food policies have redistributive effects and are therefore subject to lobbying and pressure from interest groups and used by decision-makers to influence society for both economic and political reasons. Some policies, such as import tariffs or export taxes, have clear distributional objectives and reduce total welfare by introducing distortions in the economy. Other policies, such as food standards, land reforms, or public investments in agricultural research, may increase total welfare but at the same time also have distributional effects. These distributional effects will influence the preferences of different interest groups and thus trigger political action.

The inherent interlinkage between efficiency and equity issues in policymaking meant that for much of history, economics and politics were closely related disciplines, often written about by the same authors, as reflected in the works of the original architects of the economics discipline-Adam Smith, John Stuart Mill, David Ricardo, and so on. In the late 19th century the economics discipline started separating itself from the "political economy" framework. The revival (or return) of political economy started in the 1950s and 1960 s and was referred to as "neoclassical political economy" or "new political economy," as economists started using their economic tools to analyze how incentives of political agents and constraints of political institutions influenced political decision-making. The start of this field is often associated with

1 This chapter is a revised version of J. Swinnen, "The Political Economy of Agricultural and Food Policies," chapter 21 in Handbook of Agricultural Economics, edited by G. Cramer, K. P. Paudel, and A. Schmitz, 381-398 (Oxon, UK: Routledge Publications, 2018). The material is reproduced with permission of the Licensor through PLSclear. For a more extensive discussion on all the issues discussed in this chapter and data illustrations, see also Swinnen (2018). 
such publications as An Economic Theory of Democracy (Downs 1957), The Logic of Collective Action (Olson 1965), The Calculus of Consent (Buchanan and Tullock 1962), classic papers by Krueger (1974) and Bhagwati (1982) on "rent-seeking," and by Stigler (1971) and Becker (1983) on political economy theories of regulation.

These theories and insights have been applied to analyze food and agricultural policies, in particular to the puzzling question: Why was agriculture subsidized in rich countries and taxed in poor countries? The combination of an intriguing question, new theories to apply, and fascinating data induced a rich literature on the political economy of agricultural trade and distortions in the 1980s and the first part of the 1990s. Later, interest in the political economy of agricultural policies was sparked by a combination of fresh data, new theories, and novel intriguing questions. New political economy models focused on the role of institutions in economic policies (for example, Acemoglu 2003 and Persson and Tabellini 2000); better microfoundations for analyzing political economy decision-making (Grossman and Helpman 1994); and the role of (mass) media (McCluskey and Swinnen 2010; Strömberg 2004).

New datasets improved indicators on institutional and political variables. The World Bank's project on distortions to agricultural incentives provided novel and rich datasets (Anderson 2009, 2016). Studies focused on how major institutional and political reforms had affected agricultural policy. This includes the global shift from state-controlled to market-based governance of agricultural and food systems, not only in China and the former Soviet Union but also in Latin America and Africa (Swinnen and Rozelle 2006). Another question related to the impact of changes in international organizations and trade agreements, such as the Uruguay Round Agreement on Agriculture (URAA), the World Trade Organization (WTO), the North American Free Trade Agreement (NAFTA), the enlargement of the EU, and so on.

The turnaround in global agricultural and food markets in the second half of the 2000s induced new economic and political debates on agricultural and food policies. Instead of export subsidies and import tariffs, export barriers and price ceilings were introduced to prevent food prices from rising. The food crisis also drew attention to the failure of agricultural policies to stimulate investment and productivity growth. Another emerging issue was whether there is a shift from traditional trade barriers (such as import tariffs) to so-called nontariff measures. This was triggered by the rapid growth in public and private standards in global agrifood chains and a concern that with binding WTO constraints on tariffs, governments were looking for other instruments to protect their markets. 
Political considerations are crucial to understanding these various agricultural and food policies of developing and developed countries. After a discussion on political models and coalitions, this chapter starts with the political economy of policies motivated primarily by redistributing income (or rents) between different groups in society, such as price and trade interventions in agricultural and food markets. The later sections focus on policies that may stimulate growth or reduce externalities but also redistribute income at the same time, such as standards and policies to reduce volatility as well as investments in public goods (research).

\section{Political Coalitions in Agricultural and Food Policies}

Political economy models of agricultural and food policy often consider producers, consumers, and taxpayers as the main groups with vested interests in policy outcomes. One (theoretical) reason is its didactic use-that is, to avoid unnecessary complications in deriving policy effects and identify equilibria. Another (empirical) reason is the absence of disaggregated information on policy impacts on various agents within (or outside) the value chain. It is, of course, well-known that in reality many more agents lobby governments to introduce or remove certain policies, including land owners, seed and agrochemical companies, rural banks, traders, food processors, retail companies, and so on. These agents may be differently affected by policies, depending on the nature of the policy_for example, whether the policy is targeted to a (raw) agricultural commodity or to a processed commodity, or whether farm subsidies affect land or other production factors.

As a consequence, these different agents have sometimes joined forces ("political coalitions") with farmers or with final consumers to influence policymakers in setting public policies. In other cases they have opposed each other on policy issues. For example, sugar processors and farmers may jointly lobby for sugar import tariffs or quotas but may oppose each other when governments consider regulating sugarcane or beet prices. In addition, the separation of interests may be less clear in reality than in models. For instance, poor farmers are affected both as producers and consumers of food, agribusinesses may own farms, and so on. These coalitions are also not static. There are several reasons why political coalitions may change: traditional power structures within value chains may change with some (sub)sectors growing and others declining with economic development, new technologies may bring new players into the value chains, new policy instruments may be introduced (or 
considered), and so on. As an illustration, consider changed coalitions because of "new players" that have emerged, or because the same players are interested in "new things."

New players have emerged for a variety of reasons. Technological advances, such as biotechnology and genetically manipulated (GM) crops, have created new vested interests - and changed those of others. In the 1970s there was no pro- or anti-GM lobby since there was no GM. Biofuels have emerged as an important factor in agricultural markets and food policy in response to rising oil prices and the search for renewable energy sources. Awareness of environmental issues and the lobbying of environmental organizations has increased. In countries such as those in the EU, environmental concerns have traditionally been less important in agricultural policy. This is different from the United States, where the 1930s Dust Bowl led to the introduction of a major conservation payment program.

The emergence of new policies, such as crop insurance subsidies, have brought new sectors, such as insurance companies, into the lobbying game for farm support programs. Growing concentration in retail and the emergence of preferred supplier systems have made the retail sector a more powerful sector in the value chain. This may benefit consumers, since for many agricultural policy issues consumer and retailer interests are aligned and therefore their political coalition may be reinforced by growing retail concentration. Vested interests may also change. In poor countries, for example, consumer interests are centered on having sufficient food at low prices. As incomes grow, however, consumers become more concerned with the quality of their food and with environmental and ethical standards of their food. With income growth and globalization, consumers are interested in local foods, while farm groups see it as a potential way of marketing and protecting their products. At the policy front, this has resulted in regulations on geographical indications (GI) -an issue that has created tensions in trade negotiations (Josling 2006; Huysmans and Swinnen 2019; Raimondi et al. 2020).

Finally, the spread of "global value chains" in recent decades is transforming not just the economics of production and exchange in the world but also the political economy of agricultural and food policies. Interest groups beyond borders have always played a role in agricultural and food policy. For example, in the 1990s the US company Monsanto actively lobbied the European governments to allow GMOs in Europe. However, with the growth of global value chains the distinction between "domestic interests" and "foreign interests” is no longer as obvious (Antràs 2015; Olper 2016). For example, if companies are sourcing inputs from foreign subsidiaries or contracting with 
foreign farms or companies for their raw materials, the policy interests of these (domestic) companies may be aligned with their (foreign) input suppliers. This integration of production and exchange in global value chains changes the incentives of agents in the value chains to lobby for or against import protection and integration in international trade agreements (Blanchard and Matschke 2015). For example, Blanchard, Brown, and Johnson (2017) and Gawande, Hoekman, and Cui (2015) show that protection is lower when the domestic content of foreign-produced final goods is higher and (vice versa) for foreign content of domestically produced goods. In other words, the integration of economies and companies in global value chains tends to dampen the incentives for protectionist policies.

\section{Price and Trade Interventions}

In the second half of the 20th century, there were major differences in agricultural and food policies between poor countries, where farmers were taxed, and rich countries that subsidized farmers (and taxed consumers). This difference was not only huge, it was also counterintuitive (Krueger, Schiff, and Valdés 1991). In countries where farmers were the majority of the population, they were losing out from agricultural policies that imposed a significant tax on them. In contrast, in countries where farmers were a small minority, farmers were subsidized, despite the fact that their numbers in the political arena had declined. This observation was referred to as "the development paradox." Political economy studies have since explained that the differences in agricultural policies between rich and poor countries captured in the development paradox are due to differences in political economy equilibria caused by the combination of structural economic differences, information costs, changes in governance structures, and so on (Anderson, Rausser, and Swinnen 2013).

\section{Structural Change and Political Incentives}

The structural changes that accompany economic development alter the costs and benefits of policies to various interest groups, and thus the incentives for political activities to be undertaken to influence governments. These, in turn, determine the government's political incentives and adjust the political economy equilibrium (Anderson 1995; Gardner 1987; Swinnen 1994). First, economic growth typically coincides with a rise in urban-rural income disparities, as growth in industry and services outpaces growth in the agricultural sector, whose specific assets make it slow to adjust. This income gap creates incentives for farmers and agricultural companies to demand-and politicians to 
supply-policies that redistribute income to reduce that income gap. Several mechanisms presented in the political economy literature explain these countercyclical policies. One is the "relative income hypothesis" of de Gorter and Swinnen (1993), driven by changes in marginal utility that in turn determine political incentives for governments to respond to interest groups. Another is the "loss aversion" argument, where political action is driven by interest groups who want to avoid losses coming from changing market conditions (Freund and Ozden 2008; Tovar 2009).

Second, in a poor economy most workers spend a large share of their income on food. They will therefore strongly oppose an increase in food prices through government interventions, such as import tariffs. Industrial capital will support worker opposition against food price increases because they are concerned about the inflationary effects on wages and their profits. In contrast, workers in rich countries generally spend a (much) smaller share of their income on food, and only a relatively small part of this is the cost of raw materials (agricultural products). This effect is reinforced by declining opposition from industry as the inflationary pressure on wages from agricultural protection declines.

Third, for a given per capita subsidy to farmers, it takes a much larger per capita tax on consumers (or workers in other sectors) when there are many farmers and fewer consumers (as in poor countries) than when there are few farmers and many consumers (workers in other sectors) as in rich countries. In other words, even though the share of farmers in the voting population declines, less opposition to protecting farmers arises when there are fewer of them. Swinnen (1994) shows that under plausible assumptions, the second of those two effects dominates. The combination of these factors causes a shift in the political economy equilibrium from taxing farmers to subsidizing farmers with economic growth.

\section{Political Organization}

Improvements in rural infrastructure with economic development also enhance farmers' ability to organize for political action. Olson (1965) explained that collective action by relatively large groups is difficult because of free-riding incentives, implying that in poor countries it is costly to politically organize farmers. Consumers are often concentrated in cities, where coordination and collective action are easier than in the rural areas. However, as the number of farmers declines and rural infrastructure improves, the cost of political organization for farmers decreases. In addition, the growth and concentration of agribusinesses and food-processing companies, which are often 
aligned with farm interests in lobbying for agricultural policies, strengthen pro-farm interests. In many countries the growth of agricultural protection has been associated with the growth of cooperative agribusiness and foodprocessing companies. ${ }^{2}$

\section{Information Costs}

Information plays a crucial role in political markets, organization, and policy design. Downs's (1957) "rationally ignorant voter" principle explains that it is rational for voters to be ignorant about certain policy issues if the costs of information are higher than the (potential) benefit of being informed. Rational ignorance, be it in the political arena ("voters") or in the economic arena ("consumers"), remains relevant despite reductions of information costs with the growth of mass media and social media (McCluskey and Swinnen 2004). People's opportunity costs and ideological differences between the information (media) source and the reader limit information consumption. The rationally ignorant voter argument implies that policies will be introduced that create concentrated benefits and dispersed costs (Stromberg 2004). This information effect reinforces the distributional effects caused by structural factors.

In addition, enhanced rural communication infrastructure, either through public investments (as in many high-income countries earlier in the 20th century) or through technological innovations and commercial distributions (as in the spread of mobile phone use in developing countries), reduces the relative costs of information in rural areas compared to urban areas. As a consequence, farmers are better informed about policies and they can use this enhanced information infrastructure to organize themselves better, improving the effectiveness of their lobbying activities. Several information-related aspects of economic development thus cause a shift in the political economy equilibrium from supporting consumers to supporting farmers (Olper and Swinnen 2013).

\section{Political Reforms}

There is a correlation between political regimes and economic development, with democratic regimes more prominent among richer countries than among poorer. Median-voter models predict that democracies tend to redistribute from the rich to the poor because the distribution of political power

2 Econometric studies by Gawande and Hoekman (2006) and López (2008) also show the influence of agribusiness and food companies' political contributions on US policies. 
(measured by votes) is typically more equal than the distribution of income and wealth (Alesina and Rodrik 1994; McGuire and Olson 1996). As farmers are typically poorer, this suggests that farmers may benefit from democratization. Moreover, the same factors that make it difficult for farmers to organize politically in poor countries (such as their large number and geographic dispersion) render them potentially powerful in electoral settings (Bates and Block 2010; Varshney 1995).

It has been difficult to measure this empirically because of data and econometric constraints. Swinnen, Banerjee, and de Gorter (2001) use long-run data and find that changes in electoral rules that have disproportionately benefited agriculture (for example, extending voting rights to small farmers and tenants) have induced an increase in agricultural protectionism. Other electoral changes have not affected agricultural protection because they increased the voting power of both those in favor and those against protection. Olper, Fałkowski, and Swinnen (2014) analyze the impact of all democratic reforms in the world since the 1960s (which were concentrated in developing and emerging countries) and find that, on average, democratization has benefited farmers.

\section{Policy Instrument Choice}

The distortionary effects of government interventions are equally dependent on the choice of the instrument as on the level of the intervention. There is an extensive literature comparing the transfer efficiency and the distortions of various policy instruments in trade and agricultural policies (Alston and James 2002; Gardner 1983). The differences in distortionary effects of policies play an important role in policy discussions and trade negotiations.

Another stylized fact of agricultural and food policies is the "anti-trade bias" - that is, that import-competing sectors are protected by taxing imports, and exportable sectors are taxed more, thereby reducing exports (Anderson 2016). Trade-policy instruments are the most important agricultural and food policies to redistribute income between consumers and producers. In earlier history they were often the only policies but even today remain very important (Anderson, Ivanic, and Martin 2013). From 2007 through 2012 the antitrade bias took on a particular version as many governments responded to rising food prices on world markets by restricting (sometimes outright banning) food exports, thereby exacerbating global price spikes (Anderson, Ivanic, and Martin 2014; Pinstrup-Andersen 2014). 
There are several reasons why trade policies are used. First, importcompeting sectors have lower comparative advantage than exporting sectors. Since benefits from market returns are lower in sectors with a comparative disadvantage, those sectors' incentives to seek income from government support are also relatively higher. In these (sub)sectors, returns to investment in lobbying activities dominate returns from market activities and so indirectly support an anti-trade bias. A second factor is the so-called revenue motive of public policy. Tariff revenues and export taxes increase government revenues and improve their terms of trade while export and import subsidies do the opposite. Third, distortions (deadweight costs) and budgetary costs of policy intervention typically increase with higher supply elasticities (Gardner 1983; de Gorter, Nielson, and Rausser 1992). Sectors with higher supply elasticities (typically exports) will be subsidized less because it is more costly to do so and causes more distortions (Becker 1983; Gardner 1987).

Fourth, policy instruments differ not only in deadweight costs but also in implementation costs. The most obvious explanation for the broad use of trade taxes (either import tariffs or export taxes) is that they are easiest and least costly to implement (Dixit 1996; Rodrik 1995). In many developing countries, tax-collection institutions are weakly developed and trade taxes (import tariffs or export taxes) are often an important-or the only substantive-source of tax revenue. In this case governments have greater incentives to use to assist farmers. Fifth, policy instruments also differ in their "transparency," the information available concerning policies, and their incidence. Politicians have an incentive to use policies that hide their costs or use policies that obfuscate the transfer itself (Magee, Brock, and Young 1989). This obfuscation perspective helps explain why nonbudget methods of redistribution, such as tariffs, are politically preferable to direct subsidies. Sixth, governments may prefer distortionary policies, such as tariffs, when they have imperfect information on their target group or the amount of transfer needed (Foster and Rausser 1993; Mitchell and Moro 2006). The total transfers-even with deadweight costsmay be lower than would be the case with direct (lump-sum) transfers when governments need to secure a minimum amount of political support. The combination of these political economy forces thus causes anti-trade bias.

These political factors can be constrained if the counterpressure is strong enough - for example, by integrating them into international trade agreements where (economic and political) costs and benefits can be weighed and compensated. In particular, the WTO has had a significant impact on the anti-trade bias and on policy instrument choice. 


\section{Policy Reforms in the Late 20th and Early 21st Century}

In past decades there has been a change in the trend of agricultural protection and in policy instruments for several high-income countries. In the second half of the 20th century, for example, agricultural protection was high and coupled policies were the most important instrument in OECD countries, consistent with the strong anti-trade bias. ${ }^{3}$ For instance, in the 1990s the average producer support estimate (PSE) of OECD countries was 30 percent to 35 percent, and the vast majority (more than 80 percent) of this support was in the form of coupled subsidies. Around the turn of the century, some important policy reforms in OECD countries brought down both total support and the amount of trade distortions. By the mid-2010s the average PSE was below 20 percent, and coupled support had fallen to around 50 percent (OECD 2019).

The implementation of GATT and the WTO have contributed importantly to policy reforms and to reducing the anti-trade bias in OECD countries (Swinnen, Olper, and Vandemoortele 2012). The collapse of Communist regimes and their distortive agricultural policies around the same period also contributed. In Eastern Europe and the former Soviet Union, economic and political liberalizations removed much of the heavy subsidies to farms that existed under the Communist regimes in the second half of the 20th century (Rozelle and Swinnen 2004). At the same time, developing countries have increased support to agriculture, primarily by reducing taxation of agricultural exports (Anderson 2009). The dominance of trade policies remains but the anti-trade bias has declined in recent decades, mainly owing to macroeconomic and trade policy reforms that reduced taxation of farmers and the antitrade bias in developing countries. These political economy changes are due to economic growth, structural adjustments, and changes in information costs and governance structures, as explained earlier.

Anderson Rausser, and Swinnen (2013, p. 7) concluded that "since the 1980 s, both the anti-agricultural bias in developing countries and the proagricultural bias in high-income countries have diminished and the two groups' average rates of assistance to agriculture have converged toward zero." This means that-rather that the divergence observed in the 1950s through the 1980s-there is now convergence in agricultural policies (see Chapter 13,

3 "Coupled PSE" includes all policy transfers (such as tariffs, price support, and subsidies) directly linked ("coupled") to agricultural production. These instruments are typically the most distortive. The second group of instruments ("decoupled") includes decoupled agricultural payments. These instruments are generally considered the least distortive. 
in this volume). The EU and China illustrate this convergence well. A significant factor in the overall decline in OECD country support was the reforms of the EU's Common Agricultural Policy (CAP), which made up a substantial share of OECD farm subsidies. Both the level of EU subsidies and their distortions have significantly decreased since 1990. The 1994 Uruguay Round Agreement on Agriculture (URAA) of the GATT/WTO played a crucial role in this. ${ }^{4}$ Further major changes in policy instruments from market interventions to direct payments increased the visibility of the transfers, as they occupied a large share of the EU's budget. This increased transparency of the transfers may have been an additional cause of reforms in the EU: over the past two decades, taxpayers have continuously pressured the EU's leaders to reduce agricultural subsidies.

China is another fascinating case of the political economy of agricultural and food policies. China is currently spending around US $\$ 200$ billion per year on subsidies to farmers-much more than any other country in the world (OECD 2017). This is a huge turnaround from the situation in the 1950s and 1960s, when the Chinese countryside was characterized by hunger and poverty due to a policy system that caused enormous inefficiencies and imposed heavy taxes on farmers. Over this period the Chinese government has shifted from taxing farmers to heavily subsidizing agriculture, and now China spends more on agricultural subsidies than any other country in the world. Not surprisingly, this dramatic policy shift has coincided with a similar dramatic increase in incomes in China-as the development paradox principles would suggest. Economic growth in China, as in other countries, has coincided with an increase in the rural-urban income gap (Huang and Yang 2017). This growing inequality has induced the Chinese government to support farm incomes by a variety of market interventions and direct subsidies (Hejazi and Marchant 2017).

As in the EU in the 1970s and 1980s, these interventions created large market distortions which, in combination with WTO constraints, induced a reform of Chinese agricultural subsidy programs from market interventions to direct subsidies that are less market distorting (Huang, Wang, and Rozelle 2013). Hence albeit at different times and under vastly different political regimes, both China and the EU dramatically increased agricultural subsidies during times of rapid economic growth (in the EU after World War II and in

4 The URAA appears to have had less impact on US agricultural policies. Nonetheless, the US administration has attempted to introduce policy reforms with an eye toward ensuring that many US agricultural subsidies are classified as "green box" (that is, non-trade distorting) under the WTO agreement (Orden, Blandford, and Josling 2010). 
China since 2000). Both first installed distortionary policy systems and later reformed their agricultural subsidy systems to less distortionary policy instruments; both capped their subsidy levels, after accession to the WTO.

\section{Price Shocks and Political Economy of Aid and Food Policy}

With a brief exception in the early 1970s, when prices moved up after the first oil crisis, for the past 50 years global agricultural markets were characterized by relatively stable and low prices. Most of the global agricultural and food policy discussions focused on the reduction of taxes on farmers in developing countries and the removal of policies that subsidized farmers in rich countries. This changed with dramatic increases in food prices in the 2000s. Urban consumers across the world protested, and governments reacted rapidly to the price spikes. Many governments-particularly in developing and emerging countries-intervened to reduce the effect of the global food price spikes (Barrett 2014; Naylor 2014; Pinstrup-Andersen 2014). Governments used price and trade policies to counter global price movements and to insulate the domestic market from the international price spikes (Demeke, Pangrazio, and Maetz 2009). ${ }^{5}$ At the same time, food price spikes triggered media and policy attention to the broader issues of hunger and rural poverty.

\section{Trading-Off Volatility and Distortions?}

A key argument in favor of policy interventions to stabilize prices is that price volatility causes inefficiencies in demand and supply (FAO and OECD 2011; Prakash 2011; World Bank 2012). Unexpected price changes make it difficult for consumers and producers to make optimal decisions and reduces their confidence in the market and investment. However, others criticized government interventions to insulate domestic markets from global price fluctuations for (1) being ineffective, (2) causing distortions in the economy, and (3) reinforcing price fluctuations when food exporters reduced supply and food importers increased demand (Anderson, Ivanic, and Martin 2013; Ivanic and Martin 2014).

5 For example, India suspended rice exports, and Russia and Kazakhstan banned wheat exports (Martin and Anderson 2011). Countries with significant food stocks refused to release these on global markets and hoarded them for domestic purposes (Timmer 2010). At the same time, food-importing countries removed policies that would increase domestic prices, and many introduced price regulations and other interventions to restrict price increases (see chapters in Barrett 2014; Naylor 2014; Pinstrup-Andersen 2014). 
From a political economy perspective, there is nothing surprising in the way that governments have reacted to changes in world market prices. Government interventions to counter market fluctuations are a key "stylized fact" of agricultural and food policies induced by the political economy mechanism caused by the relative income hypothesis or loss aversions explained earlier in the chapter. Hence, even without taking into account possible additional benefits for consumers or producers from price stability, political mechanisms will induce governments to respond to international price increases by policy interventions that limit price rises on domestic markets by export constraints and vice versa through import tariffs when prices fall on the international markets. To integrate benefits from price stability, Pieters and Swinnen (2016) derive a socially optimal distortions-volatility trade-off that takes into account both consumer and producer benefits from stability and production and consumption distortions caused by deviations from the world market price. ${ }^{6}$ However, they find that many countries' policies during the past decade are far removed from the socially optimal distortions-volatility combinations. Hence political motives were very important.

\section{Food Prices and Global Development Policy}

The food crisis pushed food security and agricultural development from the bottom of the international development agenda toward the top of policymakers' priority list. ${ }^{7}$ The price spikes of 2007 and 2008 led to urban protests and, in a number of cases, created political instability (Cohen and Garret 2010; Maystadt, Tanb, and Breisinger 2014). This captured the attention of global policymakers and donors. As soon as urban protests reached the streets, international organizations reacted much like local politicians and paid a disproportionate amount of attention to the problems of urban consumers. Global mass media played an important role in drawing reactions and policy attention from international organizations and global policymakers (Guariso, Squicciarini, and Swinnen 2014). The price spikes, and the ensuing urban

6 Their model is based on Barrett (1996); Bellemare, Barrett, and Just (2013); and Gouel and Jean (2015).

7 After the dramatic increase of food prices in 2006 and 2008, reports emphasized that high food prices have a devastating effect on developing countries and the world's poor. Before, most reports argued that low food prices were hurting developing countries' farmers and the poor (Swinnen, Squicciarini, and Vandemoortele 2011). Only a few studies initially pointed at the mixed effects of the high food prices on poverty and food security (for example, Aksoy and Hoekman 2010; Heady 2013; Verpoorten et al. 2013). 
consumer unrest, created major "media events." ${ }^{8}$ Local media reports were picked up by international mass media, which paid a disproportionate amount of attention to the problems of urban consumers, compared to the long-run hunger and poverty problems among the rural population.

Thus, while for many years experts pointed at the low level of investment in developing country agriculture as a source of poverty and food security, it was only after the "food crisis" that media attention increased and that policymakers worldwide put rural poverty and underinvestment in agriculture on their priority list and raised donor funding. 'The "food crisis" acted as a catalyst of attention to long-standing issues related to food security and agricultural production, which were made particularly salient by the fact that urban consumers-whose voice is typically heard the most by mass media and policymakers-were hit the hardest by the spikes in food prices (Swinnen, Squicciarini, and Vandemoortele 2011). What is remarkable is that, despite the fact that rural malnutrition and poverty of farmers and low agricultural productivity in developing countries has been a major problem for a long time, it may have been an "urban (consumer) crisis" that helped to put poor farmers' situation on top of the agenda. Hence food price spikes may have succeeded where others have failed in the past: to put the problems of poor and hungry farmers on the policy agenda and to induce development policies and donor strategies to help them.

\section{The Political Economy of Food Standards}

Production and trade are increasingly regulated by stringent public and private standards on quality, safety, nutritional, environmental, and ethical as well as social aspects. An important critique is that standards are (nontariff)

8 Media attention is typically concentrated around events or shocks (Swinnen and Francken 2006). The agenda-setting effect of the media in international and aid policy has sometimes been referred to as the "CNN factor" (Hawkins 2002). A related factor is that the public at large is more interested in media reports concentrating on negative effects, the so-called bad news hypothesis (McCluskey and Swinnen 2004).

9 Between 2000 and 2005 the share of global overseas development aid (ODA) going to agriculture fell from 5 percent to 3.8 percent (OECD 2013), and the budget share in the UN system going to agriculture (FAO) fell from 20.1 percent to 15.5 percent (Global Policy Forum 2013). After the food crisis, donor funding reversed dramatically: between 2007 and 2011 the share going to agriculture (FAO) in the UN system increased from 15.2 percent to 22.2 percent, and the share of global development aid going to agriculture jumped from 3.7 percent to 6.5 percent (Global Policy Forum 2013; OECD 2013). Oxfam and global agricultural research centers, under the heading of the CGIAR, also saw their funding increase strongly (Guariso, Squicciarini, and Swinnen 2014). 
trade barriers. As trade agreements such as WTO have reduced tariffs, countries may use standards to shield their domestic markets from foreign competition (Anderson, Damania, and Jackson 2004; Brenton and Manchin 2002; Fischer and Serra 2000). Convergence (or not) of standards is at the heart of recent trade negotiations such as CEFTA (Central America Free Trade Agreement), TTIP (Transatlantic Trade and Investment Partnership), and so on.

Standards affect trade. ${ }^{10}$ However, the implicit comparison with tariffs in the trade debate is not entirely valid. In a small open economy the socially optimal tariff level is zero. A positive tariff level constrains trade, is harmful to social welfare, and is protectionist. But this is not necessarily the case for standards because this ignores the potential benefits of standards. If the standard reduces asymmetric information or externalities, there is no simple relationship between the trade effects of a standard and the social optimum (Beghin 2013; Marette 2014; Marette and Beghin 2010; Sheldon, 2012; Van Tongeren, Beghin, and Marette 2009). This result does not imply that there are no protectionist elements in standards setting. Standards can enhance aggregate welfare by reducing asymmetric information or negative externalities but can also create rents for specific interest groups. Because of the distributional effects of standards, interest groups have a vested interest in influencing governments' decisions on standards. When interest groups have differing lobbying strengths, the political equilibrium will generally differ from the social optimum.

The political equilibrium standard may be either too high or too low from a social welfare point of view. Influential lobby groups may push for both more stringent or less stringent standards depending on the relative magnitude of the price (demand) effect compared with the implementation cost (for producers) or the efficiency gain (for consumers) (Beghin, Maertens, and Swinnen 2015; Swinnen 2016). For example, if producers are more influential than consumers, overstandardization results when producers' profits increase with a higher standard and in understandardization otherwise. Higher profits for producers are more likely when the standard's price (demand) effect is large and when the implementation cost is small.

10 Only in very special circumstances do standards not affect trade: this is when the effect on domestic production exactly offsets the effect on consumption (Swinnen and Vandemoortele 2011). 


\section{Development and Pro-Standard and Anti-Standard Coalitions}

This political economy can explain the empirically observed positive relationship between standards and economic development. First, and most obvious, higher income levels are typically associated with higher consumer preferences for high quality and safety standards as reflected in higher efficiency gains. Second, the quality of institutions for enforcement of contracts and public regulations is positively correlated with development. Better institutions imply better enforcement and control of standards. Although poor countries may have a cost advantage in the production of raw materials, the better institutions of rich countries lower the marginal increase in production costs caused by standards. Third, higher education and skills of producers, better public infrastructure, easier access to finance, and so on also lower implementation costs. Fourth is the different organization and structure of the media in rich and poor countries. Mass media is the main source of information for many people. The cost of media information is higher and government control of the media is stronger in poor countries. Therefore, the media structure and information provision is likely to induce a more pro-standard attitude in rich countries than in poor, as increased access to media increases attention to risks and negative implications of low standards (Curtis, McCluskey, and Swinnen 2008).

In combination these factors are likely to induce a shift of the political equilibrium from low standards to high standards with development. A pro-standard coalition of consumers and producers in rich countries results if consumers derive large efficiency gains from a standard, while producers incur only moderate increases in costs. In contrast, an anti-standard coalition may be present in poor countries if consumers are more concerned with low prices than with high quality (leading to small efficiency gains from a higher standard) while the implementation costs for producers may be large. Structural differences in information and media may reinforce the positive relationship between standards and development.

\section{The Persistence of Standards: Dynamic Political Economics}

Some of the most important political aspects of standards relate to their dynamic effects. Dynamic political economic aspects of standards can provide an explanation for different food standards in countries with similar levels of development, such as in the EU and the United States, and why such differences may persist. ${ }^{11}$ Once adopted, countries will tend to stick to the status quo in standards because implementation costs depend on existing standards

11 See Swinnen et al. (2015) and Swinnen (2017) for more technical analysis and details. 
that resulted from past investments. Differences in standards between countries may persist because of this and trade may enforce this. The reason is that producer or consumer preferences may change in a dynamic way once the standard is introduced. ${ }^{12}$

The standard will affect comparative advantages and will thus induce producers to support maintaining the standard to protect them from (cheaper) nonstandard imports. Hence, although standards may have been introduced because of consumer demands, their persistence in the long run results from (a coalition of consumer and) producer demands. Hysteresis in standards therefore can be driven by protectionist motives even if the initial standards were not introduced for protectionist reasons. With these forces in play, standards and regulations often persist over long periods of time and their protectionist effects and inefficiencies may increase over time. Regulatory differences among countries may cause major conflicts over time as vested interests and industries, which have invested in adhering to these standards, will lobby governments and international organizations to impose their own standards on foreign producers.

That said, there are many examples of standards and regulations that have changed over time when their use-or their vested interests-weakened (Vogel 2003). However, significant shocks to the political economy system may be required for such changes-that is, to move the political economy equilibrium to another equilibrium given the dynamic political and institutional constraints to overcome (Rausser, Swinnen, and Zusman 2012). Shocks may come from both internal and external sources. An internal source is when domestic crises affect food standards. For instance, the first wave of modern public food safety and quality regulations were induced in the late 19th century by public outrage of consumers over the use of cheap and sometimes poisonous ingredients in food production (Meloni and Swinnen 2013, 2015, 2017). In the early 21 st century, major changes in public food standards in the EU followed food safety scandals in the late 1990s, with consumers demanding better protection and triggering new policies such as traceability through

12 The case that producers have different preferences and consumers have the same is analogous. For example, Paarlberg (2008) and Zilberman et al. (2013) argue that consumers on both sides of the Atlantic tend to dislike GM technology, but agribusiness lobbying has been much more pro-GM in the United States. In the longer run it may be that as consumers live in different GM-food environments in the United States and the EU, they develop different preferences. Consumer attitudes with respect to biotechnology are likely to be endogenous. In countries where GM products are available, consumer preferences may shift in favor of this technology, while inversely consumers may distrust GM technology more in countries where GM products have been banned. 
value chains (McCluskey and Swinnen 2011). The introduction of various public regulations in China in the late 2000s followed the "milk scandal" where people died from consuming milk products with poisonous ingredients (Mo et al. 2012).

Another source of shocks is external. One example is the integration of countries with different standards through international agreements. This may either cause the removal of "inefficient standards" or the opposite: that inefficient standards are extended to other countries with international integration. In reality, both phenomena have been observed, often reflecting the bargaining power of the industries and countries where the (in-)efficient regulations were in place before integration.

\section{GMOs, Gls, and Food Definitions}

Three cases of public standards that have attracted wide attention in recent years and continue to do so are the cases of GMO regulations, GIs, and "food definitions." All of these cases represent interesting mixes of private and public interests and of changing political coalitions. Regarding GMOs, large agrochemical and seed companies as well as many NGOs have lobbied intensely to influence GM regulations around the world (Paarlberg 2001; PinstrupAndersen and Schioler 2003; Vigani and Olper 2014). While various groups tried to influence GM policy, Graff, Hochman, and Zilberman (2009) argue that the US agribusiness industry was lobbying more pro-GM than the EU agribusiness industry. Some important GM products are competing with traditional agribusiness products, especially GM traits that substitute for pesticides and insecticides. Because it threatened their traditional revenues, several large agropharmaceutical companies, such as Bayer and BASF, initially did not take a strong side in the debate-in contrast to, for example, US-based Monsanto, which lobbied strongly pro-GM. This created a very different political coalition in the United States than in the EU, contributing to a different regulatory outcome (Qaim 2009, 2016).

Second, globalization has increased the links between consumers and producers globally, but at the same time stimulated farmers to lobby for their "local products," seeking a coalition with consumers interested in local foods. At the policy front this has resulted in regulations on geographical indications (GI) - an issue that has created significant tensions in trade negotiations as the number of GIs has grown rapidly over the past 20 years, initially especially in the EU but now growing worldwide, and are an increasingly important item in trade negotiations (Josling 2006; Huysmans and Swinnen 2019; Raimondi et al. 2020). An interesting related issue is how organizations 
representing environmental interests will reinforce the "local products" coalition by pointing at the environmental costs of trade and global sourcing.

Third, another case of how standards may reduce information asymmetries and transaction costs but also protect vested interests, are the regulations that define specific foods. Historical cases include the definition of "wine" (first in France and later in the EU) and of "chocolate" in the late 19th and early 20th centuries, which had major implications for international trade in these food products a century ago and continues to affect trade and consumption patterns today (Meloni and Swinnen 2013, 2015, 2017). An interesting recent case is the definition of "meat" with technological advances and changing consumer preferences. As plant-based "meat" products have grown rapidly in recent years, US livestock farms have lobbied for regulation to prohibit companies from using words such as "meat," "burger," "sausage," and so on unless the product came from an animal. However, they face opposition from a coalition of new plant-based "meat" companies and large food companies that have invested in them.

\section{The Political Economy of Public Investments and Compensation}

There is relatively little research on the political economy of public goods and investments in agriculture. Two exceptions are the political economy of land reforms and of public investment in agricultural research. ${ }^{13}$ Public investments in research are an important source of productivity growth (Alston and Pardey 2013; Alston 2017). Studies document high social rates of return to public agricultural research investments but also that there is significant underinvestment in research in both poor and rich countries (Huffman and Evenson 1992; Ruttan 1982). One political economy explanation of the underinvestment by governments is spillover effects (or externalities) in a policy environment where government research investments in one country affect other countries. ${ }^{14}$

13 For a review of the political economy of more general public investments in agriculture, see Mogues (2015). The discussion about investment in agricultural research in this chapter is useful to understand the analysis of agricultural research in Chapter 21 of this volume.

14 Studies have also argued that benefits of public investments in agricultural research are overestimated because of deadweight costs of taxation (Fox 1985), terms of trade effects (Edwards and Freebairn 1984), the effects on unemployment (Schmitz and Seckler 1970), the increase in the deadweight costs of existing commodity policies (Alston, Edwards and Freebairn 1988; Murphy, Furtan, and Schmitz 1993), or because they ignore private research and because of lags in the effects of research (Alston and Pardey 1996). 
Research has both public and private good characteristics, as some of the benefits of research expenditures can be captured by specific groups, while other results spill over to other groups or countries (Cornes and Sandler 1986). This affects governments' incentives to invest in research. Spillover effects can thus induce free-riding behavior by governments. Governments in one country will invest less than optimal since they pay for all the costs while part of the benefits are reaped by other countries. Or, inversely, governments may think that they can reap (some of) the benefits from other countries' investments without having to bear the (full) costs of research investments (Huffman and Miranowski 1981; Khanna, Huffman, and Sandler 1994; Rose-Ackerman and Evenson 1985).

A different political economy explanation draws on the distributional effects of public investments (Baland and Kotwal 1998; de Gorter, Nielson, and Rausser 1992; de Gorter and Zilberman 1990; Rausser 1992). Although society as a whole may gain from public investments, different groups in society may have different preferences, depending on how it affects their personal welfare. They will prefer the government to choose their private optimum level of research and will negatively react to the government's choice if this diverges from their private optimum. If some groups oppose public investments because of income distribution effects, governments will underinvest in public goods as they balance the political costs and benefits of diverging from the social optimum.

For example, public investments in research have contributed to the dramatic increase in productivity of agriculture during the 20th century. This productivity increase contributed to the long-term decline in agricultural prices. Although this benefited food consumers, it put pressure on farm incomes (Alston 2017; Ruttan 1982). Coauthors de Gorter and Swinnen (1998) show that in general with unequal income distributional effects a government maximizing political support will underinvest in public research, both in rich countries and in poor countries. Gardner (1987) and Oehmke and Yao (1990) indeed find that underinvestment occurs if farmers gain relatively less from research.

\section{Policy Interactions}

So far this chapter has analyzed the political economy of various policies in isolation, meaning as if there were no other policies. However, in reality, many public policies exist simultaneously and may interact with each other. One can distinguish between "economic interaction effects" (EIEs), which arise if one policy affects the distributional and welfare effects of other 
policies, and "political interaction effects" (PIEs), which occur when one policy affects the political incentives of governments to introduce or change other policies.

One form of (positive) EIE is when combined reforms reinforce the (beneficial) impacts of separate policy reforms. For example, in the reform strategies in China and Eastern Europe in the 1990s, land reforms and privatization strategies provided new opportunities and better incentives for farmers, while at the same time distortionary price and market policies were reduced or removed. In these cases, both policy reforms combined to improve efficiency. An example of (negative) EIEs is the interaction between public agricultural research and commodity policies that regulate agricultural prices or production. Agricultural research increases productivity and may cause an increase in distortions of existing regulations. Under some conditions the research benefits may be outweighed by increased distortions (Alston, Edwards, and Freebairn 1988; Murphy, Furtan, and Schmitz 1993; Swinnen and de Gorter 1993).

An example of PIEs is the use of agricultural policies for compensation purposes. Compensation is an important element in the political economy of policy reform or public investment (Rausser, Swinnen, and Zusman 2012). ${ }^{15}$ Reforms to a more efficient policy almost always imply gains for some groups and losses for others. Similarly, building a road may lead to major gains in rural development but may hurt those who have to move to allow the construction of the road. If the gains outweigh the losses, it is socially optimal to implement the reforms or make the investment since the gains of those who win are more than sufficient to compensate the losers. There are numerous empirical examples of "policy packages" that include compensation for certain groups. They are a traditional part of multiannual agricultural policy decision-making both in the EU and in the United States.

An important problem with compensation, however, is the credible implementation of such schemes. Those who lose from reform may oppose the reforms if they expect that (full) compensation will not take place. The latter may be the case when governments lack the credibility to effectively provide compensation when the reform effects emerge (Acemoglu and Robinson 2006; Swinnen and de Gorter 2002), when governments only offer partial

15 Trade policy reform and compensation have a long history in the economics literature, going back to the early analyses of Adam Smith and David Ricardo. A crucial element in the arguments on the optimality of free trade are that the gains of the winners of trade liberalization are more than sufficient to compensate the losers of reform, an issue that has clearly become highly relevant again in recent years with discussions on the gainers and losers from globalization. 
compensation to mitigate political opposition sufficient to get the reforms through (Foster and Rausser 1993), when local institutions prevent the creation of effective compensation schemes (Swinnen 1997), or when there is uncertainty on the effect of the reforms-and thus on who will be the losers and gainers of the reforms (Fernandez and Rodrik 1991).

The inability of governments to credibly commit to compensate groups that are adversely affected is a prime cause of underinvestment in public goods or of failures to implement aggregate welfare improving policies more generally. An important question is therefore how to design mechanisms that constrain policymakers, to bring the discretionary political equilibrium closer to the social optimum. The creation of institutions that make policy reversal more difficult enhances the credibility of policymakers to commit to future compensation. Examples of such institutions are independent central banks for monetary policy or international trade agreements that impose constraints on government policies in agriculture and food. Another example is the role that the WTO has played in preventing the return to agricultural protectionism in recent years during periods of price fluctuations.

\section{References}

Acemoglu, D. 2003. "Why Not a Political Case Theorem? Social Conflict, Commitment, and Politics." Journal of Comparative Economics 31 (4): 620-652.

Acemoglu, D., and J. Robinson. 2006. Economic Origins of Dictatorship and Democracy. Cambridge: Cambridge University Press.

Aksoy, M. A., and B. Hoekman. 2010. Food Prices and Rural Poverty. Washington, DC: World Bank.

Alesina, A., and D. Rodrik. 1994. "Distributive Politics and Economic Growth." Quarterly Journal of Economics 109 (2): 465-490.

Alston, J. M. 2017. Fellows Address. "Reflections of Agricultural R\&D, Productivity, and the Data Constraint: Unfinished Business, Unsettled Issues.” Proceedings of the American Journal of Agricultural Economics Conference, Chicago, August.

Alston, J. M., G. W. Edwards, and J. W. Freebairn. 1988. "Market Distortions and Benefits from Research." American Journal of Agricultural Economics 70: 281-288.

Alston, J. M., and J. S. James. 2002. "The Incidence of Agricultural Policy.” In The Handbook of Agricultural Economics, vol. 2, edited by B. Gardner and G. Rausser, 2073-2123. Amsterdam: Elsevier Science. 
Alston, J. M., and P. Pardey. 1996. Making Science Pay: The Economics of Agricultural Re'D Policy. Washington, DC: AEI Press.

. 2013. "Agricultural R\&D and Food Security of the Poor." Economic Papers 32 (3): 289-297.

Anderson, K. 1995. "Lobbying Incentives and the Pattern of Protection in Rich and Poor Countries." Economic Development and Cultural Change 43 (2): 401-423.

-2016. Agriculture Trade, Policy Reforms, and Global Food Security. Palgrave Studies in Agriculture Economics and Food Policy book series (AEFP). London: Palgrave Macmillan.

Anderson, K., ed. 2009. Distortions to Agricultural Incentives: A Global Perspective, 1955-2007. London: Palgrave Macmillan; Washington, DC: World Bank.

Anderson, K., R. Damania, and L. A. Jackson. 2004. “Trade, Standards, and the Political Economy of Genetically Modified Food." Discussion Paper 4526. Centre for Economic Policy Research.

Anderson, K., M. Ivanic, and W. Martin. 2014. "Food Price Spikes, Price Insulation, and Poverty." In The Economics of Food Price Volatility, edited by J-P Chavas, D. Hummels, and B. Wright, 311-344. Chicago: University of Chicago Press.

Anderson, K., G. C. Rausser, and J. Swinnen. 2013. "Political Economy of Public Policies: Insights from Distortions to Agricultural and Food Markets." Journal of Economic Literature 51 (2): 423-477.

Anderson, K., and J. Swinnen, eds. 2008. Distortions to Agricultural Incentives in Europe's Transition Economies. Washington, DC: World Bank.

Antràs, P. 2015. Global Production: Firms, Contracts and Trade Structure. Princeton, NJ: Princeton University Press.

Baland, J. M., and A. Kotwal. 1998. “The Political Economy of Underinvestment in Agriculture.” Journal of Development Economics 55 (1): 233-247.

Barrett, C. B. 1996. “On Price Risk and the Inverse Farm Size-Productivity Relationship.” Journal of Development Economics 51 (2): 193-215.

-2014. Food Security and Sociopolitical Stability. Oxford: Oxford University Press.

Bates, R. H., and S. Block. 2010. "Agricultural Trade Interventions in Africa." In The Political Economy of Agricultural Price Distortions, edited by K. Anderson, 304-331. Cambridge: Cambridge University Press.

Becker, G. S. 1983. "A Theory of Competition among Pressure Groups for Political Influence.” Quarterly Journal of Economics 98 (August): 371-400.

Beghin, J. 2013. Nontariff Measures with Market Imperfections: Trade and Welfare Implications. Volume 12 of Frontiers of Economics and Globalization. Bingley, UK: Emerald. 
Beghin, J., M. Maertens, and J. Swinnen. 2015. "Nontariff Measures and Standards in Trade and Global Value Chains." Annual Review of Resource Economics 7: 425-450.

Bellemare, M. F., C. B. Barrett, and D. R. Just. 2013. "The Welfare Impacts of Commodity Price Volatility: Evidence from Rural Ethiopia." American Journal of Agricultural Economics 95 (4): 877-899.

Bhagwati, J. N. 1982. "Directly Unproductive Profit Seeking Activities: A Welfare Theoretic Synthesis and Generalization." Journal of Political Economy 90: 988-1002.

Blanchard, E. J., C. P. Bown, and R. C. Johnson. 2017. Global Supply Chains and Trade Policy. NBER Working Paper 21883. Cambridge, MA: National Bureau of Economic Research.

Blanchard, E. J., and X. Matschke. 2015. "U.S. Multinationals and Preferential Market Access." Review of Economics and Statistics 97 (4): 839-854.

Brenton, P., and M. Manchin. 2003. "Making EU Trade Agreements Work: The Role of Rules of Origin." The World Economy 26 (5): 755-769.

Buchanan, J. M., and G. Tullock. 1962. The Calculus of Consent. Ann Arbor, MI: University of Michigan Press.

Cohen, M. J., and J. L. Garrett. 2010. "The Food Price Crisis and Urban Food (In)security.” Environment and Urbanization 22: 467-482.

Cornes, R., and T. Sandler. 1986. The Theory of Externalities, Public Goods, and Club Goods. Cambridge: Cambridge University Press.

Curtis, K. R., J. J. McCluskey, and J. Swinnen. 2008. "Differences in Global Risk Perceptions of Biotechnology and the Political Economy of the Media." International Journal of Global Environmental Issues 8 (1/2): 77-89.

de Gorter, H., D. J. Nielson, and G. C. Rausser. 1992. "Productive and Predatory Public Policies: Research Expenditures and Producer Subsidies in Agriculture.” American Journal of Agricultural Economics 74 (1): 27-37.

de Gorter, H., and J. Swinnen. 1998. “The Impact of Economic Development on Public Research and Commodity Policies in Agriculture." Review of Development Economics 2 (1): 41-60.

de Gorter, H., and D. Zilberman. 1990. "On the Political Economy of Public Good Inputs in Agriculture." American Journal of Agricultural Economics 72: 131-137.

Demeke, M., G. Pangrazio, and M. Maetz. 2009. “Country Responses to the Food Security Crisis: Nature and Preliminary Implications of the Policies Pursued.” FAO Initiative on Soaring Food Prices. Rome: FAO.

Dixit, A. K. 1996. The Making of Economic Policy: A Transaction Cost Politics Perspective. Cambridge, MA: MIT Press. 
Downs, A. 1957. An Economic Theory of Democracy. New York: Harper and Row.

Edwards, G. W., and J. W. Freebairn. 1984. "The Gains from Research into Tradable Commodities." American Journal of Agricultural Economics 66: 41-49.

FAO (Food and Agriculture Organization of the United Nations) and OECD (Organisation for Economic Co-operation and Development), eds. 2011. "Price Volatility in Food and Agricultural Markets: Policy Responses.” Paris: OECD.

Fernandez, R., and D. Rodrik. 1991. "Resistance to Reform: Status Quo Bias and the Presence of Individual Specific Uncertainty." American Economic Review 81: 1146-1155.

Fischer, R., and P. Serra. 2000. "Standards and Protection." Journal of International Economics 52 (2): 377-400.

Foster, W. E., and G. C. Rausser. 1993. "Price-Distorting Compensation Serving the Consumer and Taxpayer Interest." Public Choice 77 (2): 275-291.

Fox, G. C. 1985. “Is the United States Really Underinvesting in Agricultural Research?” American Journal of Agricultural Economics 67: 806-812.

Freund, C., and C. Ozden. 2008. “Trade Policy and Loss Aversion.” American Economic Review 98 (4): 1675-1691.

Gardner, B. L. 1983. "Efficient Redistribution through Commodity Markets." American Journal of Agricultural Economics 65 (2): 225-234.

. 1987. "Causes of U.S. Farm Commodity Programs." Journal of Political Economy 95 (2): $290-310$.

Gawande, K., and B. Hoekman. 2006. "Lobbying and Agricultural Trade Policy in the United States." International Organization 60: 527-561.

Gawande, K., B. Hoekman, and Y. Cui. 2015. "Global Supply Chains and Trade Policy Responses to the 2008 Crisis." World Bank Economic Review 29 (1): 102-128.

Global Policy Forum. 2013. Global Policy Forum - Financing of the UN Programmes, Funds and Specialized Agencies. Accessed June 2014. www.globalpolicy.org/un-finance/tables-and -charts-on-un-finance/the-financing-of-the-un-programmes-funds-and-specialized-agencies .html

Gouel, C., and S. Jean. 2015. "Optimal Food Price Stabilization in a Small Open Developing Country.” World Bank Economic Review 29 (1): 72-101.

Graff, G. D., G. Hochman, and D. Zilberman. 2009. "The Political Economy of Agricultural Biotechnology Policies." AgBioforum 12 (1): 34-46.

Grossman, G. M., and E. Helpman. 1994. "Protection for Sale." American Economic Review 84 (4): 833-850. 
Guariso A., M. P. Squicciarini, and J. Swinnen. 2014. "Food Price Shocks and the Political Economy of Global Agricultural and Development Policy." Applied Economic Perspectives and Policy 36 (3): 387-415.

Hawkins, V. 2002. "The Other Side of the CNN Factor: The Media and Conflict." Journalism Studies 3 (2): 225-240.

Headey, D. 2013. “The Impact of the Global Food Crisis on Self-Assessed Food Security.” World Bank Economic Review 27 (1): 1-27.

Hejazi, M., and M. A. Marchant. 2017. “China’s Evolving Agricultural Support Policies.” Choices $32(2): 1-7$.

Huang, J., X. Wang, and S. Rozelle. 2013. “The Subsidization of Farming Households in China's Agriculture." Food Policy 41: 124-132.

Huang, J., and G. Yang. 2017. "Understanding Recent Challenges and New Food Policy in China, Global Food Security.” Global Food Security 12: 119-126.

Huffman, W. E., and R. E. Evenson. 1992. "Contributions of Public and Private Science and Technology to U.S. Agricultural Productivity." American Journal of Agricultural Economics 74: 751-756.

Huffman, W. E., and J. A. Miranowski. 1981. “An Economic Analysis of Expenditures on Agricultural Experiment Station Research." American Journal of Agricultural Economics 63 (1): $104-118$.

Huysmans, M., and J. Swinnen. 2019. "No Terroir in the Cold? A Note on the Geography of Geographical Indications." Journal of Agricultural Economics 70 (2): 550-559.

Ivanic, M., and W. Martin. 2014. "Implications of Domestic Price Insulation for Global Food Price Behaviour." Journal of International Money and Finance 42: 272-288.

Josling, T. 2006. "The War on Terroir: Geographical Indications as a Transatlantic Trade Conflict." Journal of Agricultural Economics 57: 337-363.

Khanna, J., W. E. Huffman, and T. Sandler. 1994. "Agricultural Research Expenditures in the United States: A Public Goods Perspective." Review of Economics and Statistics 76 (2): 267-277.

Krueger, A. O. 1974. "The Political Economy of the Rent-Seeking Society." American Economic Review 64 (3): 291-303.

Krueger, A. O., M. Schiff, and A. Valdés. 1991. The Political Economy of Agricultural Pricing Policy. Baltimore: Johns Hopkins University Press for the World Bank.

López, R. A. 2008. “Does 'Protection for Sale' Apply to the US Food Industries?” Journal of Agricultural Economics 9 (1): 25-40. 
Magee, S. P., W. A. Brock, and L. Young. 1989. Black Hole Tariffs and Endogenous Policy Theory. Cambridge: Cambridge University Press.

Marette, S. 2014. "Non-Tariff Measures When Alternative Regulatory Tools Can Be Chosen." Mimeo. UMR Economie publique INRAE-AgroParis Tech.

Marette, S., and J. Beghin. 2010. “Are Standards Always Protectionist?” Review of International Economics 18 (1): 179-192.

Martin, W., and K. Anderson. 2011. "Export Restrictions and Price Insulation during Commodity Price Booms." Policy Research Paper 5645, World Bank, Washington, DC.

Maystadt, J. F., J. Tanb, and C. Breisinger. 2014. “Does Food Security Matter for Transition in Arab Countries?” Food Policy 46: 106-115.

McCluskey, J. J., and J. Swinnen. 2004. "Political Economy of the Media and Consumer Perceptions of Biotechnology." American Journal of Agricultural Economics 86: 1230-1237.

_.2010. "Media Economics and the Political Economy of Information." In The Oxford Handbook of Government and Business, edited by D. Coen, W. Grant, and G. Wilson, 643662. Oxford: Oxford University Press.

- 2011. "Media and Food Risk Perceptions." EMBO Journal 12 (7): 467-486.

McGuire, M. C., and M. Olson Jr. 1996. "The Economics of Autocracy and Majority Rule: The Invisible Hand and the Use of Force." Journal of Economic Literature 34 (1): 72-96.

Meloni, G., and J. Swinnen. 2013. "The Political Economy of European Wine Regulations.” Journal of Wine Economics 8 (3): 244-284.

- 2015. "Chocolate Regulations." In The Economics of Chocolate, edited by M. P. Squicciarini and J. Swinnen, 268-306. Oxford: Oxford University Press.

- 2017. "Standards, Tariffs and Trade: The Rise and Fall of the Greek-French Raisin Trade and the Definition of Wine." Journal of World Trade 51 (4): 711-740.

Mitchell, M., and A. Moro. 2006. "Persistent Distortionary Policies with Asymmetric Information.” American Economic Review 96 (1): 387-393.

Mo, D., J. Huang, X. Jia, H. Luan, S. Rozelle, and J. Swinnen. 2012. “Checking into China's Cow Hotels: Have Policies Following the Milk Scandal Changed the Structure of the Dairy Sector?" Journal of Dairy Science 95 (5): 2282-2298.

Mogues, T. 2015. "Political Economy Determinants of Public Spending Allocations: A Review of Theories, and Implications for Agricultural Public Investment." European Journal of Development Research 27 (3): 452-473.

Murphy, J. A., W. H. Furtan, and A. Schmitz. 1993. “The Gains from Agricultural Research under Distorted Trade." Journal of Public Economics 51: 161-172. 
Naylor, R. L., ed. 2014. The Evolving Sphere of Food Security. Oxford: Oxford University Press.

OECD. 2013. Official Development Assistance. www.oecd.org/dac/financing-sustainable -development/development-finance-standards/official-development-assistance.htm.

- 2017. Agricultural Policy Monitoring and Evaluation 2017: OECD Countries and Emerging Economies. Paris: OECD.

- 2019. Agricultural Policy Monitoring and Evaluation 2019. Paris: OECD.

Oehmke, J. F., and X. Yao. 1990. "A Policy Preference Function for Government Intervention in the US Wheat Market." American Journal of Agricultural Economics 72 (3): 631-640.

Olper, A. 2016. "The Political Economy of Trade-Related Regulatory Policy: Environment and Global Value Chain.” Bio-Based and Applied Economics 5 (3): 287-324.

Olper, A., J. Fałkowski, and J. Swinnen. 2014. "Political Reforms and Public Policies: Evidence from Agricultural and Food Policy.” World Bank Economic Review 28 (1): 21-47.

Olper, A., and J. Swinnen. 2013. "Mass Media and Public Policy for Agriculture." World Bank Research Digest 7 (3): 6.

Olson, M. 1965. The Logic of Collective Action. New Haven, CT: Yale University Press.

Orden, D., D. Blandford, and T. Josling. 2010. “Determinants of United States Farm Policies.” In The Political Economy of Agricultural Price Distortions, edited by K. Anderson, $162-$ 190. Cambridge: Cambridge University Press.

Paarlberg, R. 2001. The Politics of Precaution: Genetically Modified Crops in Developing Countries. Washington, DC: IFPRI.

- 2008. Starved for Science: How Biotechnology Is Being Kept out of Africa. Cambridge, MA: Harvard University Press.

Persson, T., and G. Tabellini. 2000. Political Economics: Explaining Economic Policy. Cambridge, MA: MIT Press.

Pieters, H., and J. Swinnen. 2016. “Trading-Off Volatility and Distortions? Food Policy during Price Spikes." Food Policy (61): 27-39.

Pinstrup-Andersen, P., ed. 2014. Food Price Policy in an Era of Market Instability: A Political Economy Analysis. Oxford, UK: Oxford University Press.

Pinstrup-Andersen, P., and E. Schioler. 2003. Seeds of Contention: World Hunger and the Global Controversy Over GM Crops. Baltimore: IFPRI.

Prakash, A. 2011. "Why Volatility Matters." In Safeguarding Food Security in Volatile Global Markets, edited by A. Prakash, 1-27. Rome: FAO.

Qaim, M. 2009. “The Economics of Genetically Modified Crops.” Annual Review of Resource Economics 1 (1): 665-694. 
-2016. Genetically Modified Crops and Agricultural Development. New York: Springer.

Raimondi, V., C. Falco, D. Curzi, and A. Olper. 2020. “Trade Effects of Geographical Indication Policy: The EU Case." Journal of Agricultural Economics. 17 (2): 330-356.

Rausser, G. 1992. "Predatory versus Productive Government: The Case of U.S. Agricultural Policy." Journal of Economic Perspectives 6 (3): 133-157.

Rausser, G., J. Swinnen, and P. Zusman. 2012. Political Power and Economic Policy: Theory, Analysis, and Empirical Applications. Cambridge: Cambridge University Press.

Rodrik, D. 1995. “Political Economy of Trade Policy.” In Handbook of International Economics, vol. 3, edited by G. M. Grossman and K. Rogoff, 1457-1494. Amsterdam: North-Holland.

Ronnen, U. 1991. "Minimum Quality Standards, Fixed Costs, and Competition." RAND Journal of Economics 22 (4): 490-504.

Rose-Ackerman, S., and R. Evenson. 1985. "The Political Economy of Agricultural Research and Extension: Grants, Votes, and Reapportionment.” American Journal of Agricultural Economics 67 (1): 1-14.

Rozelle, S., and J. Swinnen. 2004. "Success and Failure of Reforms: Insights from Transition Agriculture." Journal of Economic Literature 42: 404-456.

Ruttan, V. W. 1982. Agricultural Research Policy. Minneapolis: University of Minnesota Press.

Schmitz, A., and D. Seckler. 1970. "Mechanized Agriculture and Social Welfare: The Case of the Tomato Harvester.” American Journal of Agricultural Economics 52: 569-577.

Sheldon, I. 2012. "North-South Trade and Standards: What Can General Equilibrium Theory Tell Us?” World Trade Review 11 (3): 376-389.

Stigler, J. G. 1971. “Theory of Economic Regulation.” Bell Journal of Economics and Management Science 2 (1): 3-21.

Strömberg, D. 2001. “Mass Media and Public Policy." European Economic Review 45 (4-6): 652-663.

_. 2004. "Mass Media Competition, Political Competition, and Public Policy." Review of Economic Studies 71 (1): 265-284.

Swinnen, J. 1994. “A Positive Theory of Agricultural Protection.” American Journal of Agricultural Economics 76 (1): 1-14.

- 1997. "Does Compensation for Disruptions Stimulate Reforms? The Case of Agricultural Reform in Central Europe.” European Review of Agricultural Economics 24 (2): 249-266.

- 2009. "The Growth of Agricultural Protection in Europe in the 19th and 20th Centuries." World Economy 32 (11): 1499-1537. 
2016. "Economics and Politics of Food Standards, Trade, and Development." Agricultural Economics 47 (S1):7-19.

_.2017. "Some Dynamic Aspects of Food Standards." American Journal of Agricultural Economics 99 (2): 321-338.

- 2018. The Political Economy of Agricultural and Food Policies. New York: Palgrave McMillan.

Swinnen, J., A. Banerjee, and H. de Gorter. 2001. "Economic Development, Institutional Change, and the Political Economy of Agricultural Protection: An Econometric Study of Belgium since the 19th Century." Agricultural Economics 26 (1): 25-43.

Swinnen, J., K. Deconinck, T. Vandemoortele, and A. Vandeplas, eds. 2015. Quality Standards, Value Chains and International Development. New York: Cambridge University Press.

Swinnen, J., and H. de Gorter. 1993. "Why Small Groups and Low Income Sectors Obtain Subsidies: The 'Altruistic' Side of a 'Self-Interested' Government." Economics and Politics 5 (3): 285-296.

- 2002. "On Government Credibility, Compensation, and Under-Investment in Public Research." European Review of Agricultural Economics 29 (4): 501-522.

Swinnen, J., and N. Francken. 2006. “Summits, Riots and Media Attention: The Political Economy of Information on Trade and Globalization." World Economy 29: 637-654.

Swinnen, J., A. Olper, and T. Vandemoortele. 2012. "Impact of the WTO on Agricultural and Food Policies." World Economy 35 (9): 1089-1101.

_ 2016. "The Political Economy of Policy Instrument Choice: Theory and Evidence from Agricultural and Food Policies." Theoretical Economics Letters 6 (1): 106-117.

Swinnen, J., and S. Rozelle. 2006. From Marx and Mao to the Market: The Economics and Politics of Agricultural Transition. New York: Oxford University Press.

Swinnen, J., P. Squicciarini, and T. Vandemoortele. 2011. "The Food Crisis, Mass Media and the Political Economy of Policy Analysis and Communication." European Review of Agricultural Economics 38 (3): 409-426.

Swinnen, J., and T. Vandemoortele. 2011. "Trade and the Political Economy of Food Standards." Journal of Agricultural Economics 62 (2): 259-280.

Timmer, C. P. 2010. “Did Speculation Affect World Rice Prices?” In The Rice Crisis: Markets, Policies and Food Security, edited by D. Dawe, 29-60. Washington, DC: FAO and Earthscan.

Tovar, P. 2009. "The Effects of Loss Aversion on Trade Policy: Theory and Evidence." Journal of International Economics 78: 154-167. 
Van Tongeren, F., J. Beghin, and S. Marette. 2009. A Cost-Benefit Framework for the Assessment of Non-Tariff Measures in Agro-Food Trade. OECD Food, Agriculture and Fisheries Working Paper 21. Paris: OECD.

Varshney, A. 1995. Democracy, Development, and the Countryside: Urban-Rural Struggles in India. New York: Cambridge University Press.

Verpoorten, M., A. Arora, N. Stoop, and J. Swinnen. 2013. “Self-Reported Food Insecurity in Africa during the Food Price Crisis." Food Policy 39: 51-63.

Vigani, M., and A. Olper. 2014. "GM-Free Private Standards, Public Regulation of GM Products and Mass Media." Environment and Development Economics 19 (6): 743-768.

Vogel, D. 2003. "The Hare and the Tortoise Revisited: The New Politics of Consumer and Environmental Regulation in Europe." British Journal of Political Science 33: 557-580.

World Bank. 2012. Responding to Higher and More Volatile World Food Prices. Washington, DC.

Zilberman, D., S. Kaplan, E. Kim, G. Hochman, and G. Graff. 2013. “Continents Divided: Understanding Differences between Europe and North America in Acceptance of GM Crops." GM Crops and Food 4: 202-208. 
